\title{
Curcuma longa on the Metabolic Profile and Atherogenic Index of Rats Fed with a Hyper Caloric Diet
}

\author{
Elen Landgraf Guiguer$^{1}$, Sandra Maria Barbalho ${ }^{1,2, *}$, Adriano Cressoni Araújo ${ }^{1}$, \\ Maricelma da Silva Soares Souza ${ }^{1}$, Patrícia Cincotto dos Santos Bueno, \\ Claudemir Gregório Mendes ${ }^{1}$, Sara da Silva Barbosa ${ }^{1}$, Eliane Paschoal da Silveira ${ }^{1}$ and \\ Daniel Pereira Coqueiro ${ }^{1}$
}

\author{
${ }^{1}$ Department of Biochemistry and Pharmacology, School of Medicine, University of Marília, Av. Higino Muzzi \\ Filho 1001, Marília - 15525-902, SP, Brazil \\ ${ }^{2}$ Department of Biochemistry and Nutrition, School of Food and Technology, FATEC-Marília, Av. Castro Alves \\ 62, Marilia - 17500-000, SP, Brazil
}

\begin{abstract}
The chronic diseases such as diabetes mellitus, metabolic syndrome and cardiovascular diseases have reached epidemic proportions in developed and developing countries. The high costs of the allopathic medicines represent a growing demand for non-allopathic alternatives. Curcuma longa is usually used as a spice in curries and as a dietary pigment and is considered a medicinal plant due important properties, with anti-inflammatory, anti-oxidant, antibacterial and anti-tumor action. The aim of this work was to evaluate the effects of Curcuma longa on the metabolic profile of Wistar rats treated with hyper caloric diet. Forty eight male rats were divided randomly into 4 groups $(n=12)$ and treated for 40 days: $\mathrm{G} 1$ that received water (Control Group); $\mathrm{G} 2$ that received condensed milk solution ad libitum; G3 that received $C$. longa by gavage route and G4 that received condensed milk solution ad libitum and $C$. longa by gavage route. No significant differences for body weight and cholesterol were observed among the groups. Visceral fat, triglycerides and glycaemia were higher in the groups treated with condensed milk but did not differ when comparing G1 with G3 and G2 with G4. Analyzing our results it is possible to say that $C$. longa may not be efficient to promote benefits in lipid and glycemic profile as well as in the body weight and visceral fat of animals treated with hyper caloric diet.
\end{abstract}

Keywords: Curcuma longa, glycaemia, cholesterol, triglycerides, HDL-c.

\section{INTRODUCTION}

In recent years the chronic diseases have reached epidemic proportions in developed and developing countries. High blood pressure, insulin resistance, dyslipidemia and weight gain are the main risk factors for developing chronic diseases such as diabetes mellitus, metabolic syndrome and cardiovascular diseases. These diseases have serious repercussions because they can interfere in the ability to work and may be related to high morbidity and mortality. The combination of these factors and the high costs of the allopathic drugs represent a growing demand for nonallopathic alternatives [1-4].

There is a long historical use of spices for medicinal purposes, and several authors are showing their potential in health. The benefits are related to a possible role in prevention or as adjuvant in the treatment of chronic diseases $[5,6]$.

Curcuma longa is usually used as spice in curries, food additive and as a dietary pigment. It is a

*Address correspondence to this author at the School of Medicine (University of Marília), Av. Higino Muzzi Filho 1001, Marília 15525-902, SP, Brazil; Tel: 00551433069434; Fax: 00551421054090; E-mail: smbarbalho@gmail.com rhizomatous perennial herbaceous plant belonging to Zingiberaceae family, native to tropical South Asia, where it was harvested for over 5,000 years. It bears many rhizomes on its root system which are the source of its culinary spice known as turmeric and its medicinal extract called curcumin. It is considered a medicinal plant due to important properties, with antiinflammatory, anti-oxidant, anti-bacterial and anti-tumor action. In Indian and Chinese traditional medicine it is used for prevention and treatment of eye infections, burns and bruises, respiratory discomfort, digestive disorders and cancer [7-12].

Turmeric possesses three major curcuminoids coumponds called curcumin, demethoxycurcumin, and bisdemethoxycurcumin. The first one is the most abundant of the three and it is known chemically as diferuloylmethane or 1,7-bis (4-hydroxy-3methoxyphenyl)-1, 6-heptadiene-3, 5-dione. Curcumin is obtained by solvent extraction of turmeric that is, the ground rhizomes of $C$. longa $[13,14]$.

\section{OBJECTIVE}

The aim of this work was to evaluate the effects of Curcuma longa on the metabolic profile of Wistar rats treated with hyper caloric diet.

(c) 2015 Lifescience Global 


\section{MATERIALS AND METHODS}

\section{Ethical Principles}

This work was approved by the Animal Research Ethics Committee of the University of Marilia (UNIMAR) with registration number 48 . The animals were treated according to the "Guide for the Care and Use of Experimental Animals" (that follows principles for the care of laboratory animals).

\section{Preparation of Aqueous Extracts of C. longa}

The extracts of $C$. longa were prepared at a concentration of $200 \mathrm{mg} / \mathrm{mL}$ (powder/water). The extract was prepared immediately before its use. The powder of the plant was obtained in local markets at Marilia city.

\section{Preparation of the Solution of Condensed Milk}

Condensed milk is a very popular product used in Brazil to the preparation of candies and cakes. Its formulation includes high percentage of sugar and fats (in $20 \mathrm{~g}$ it contains: $12 \mathrm{~g}$ of carbohydrates, $1,7 \mathrm{~g}$ of fat and $1,4 \mathrm{~g}$ of protein; 69 Kilo calories or $290 \mathrm{KJ}$ ). The solution was used to the animals of G2 and G4 groups and was prepared in a 1:1 proportion (condensed milk/water) every day immediately before its offer to the animals. Animals that received this solution instead of water were considered receiving a hyper caloric diet because the amount of carbohydrates is higher than the group that received only water and rat food.

\section{Experimental Model}

Forty eight male Wistar rats weighing approximately $250 \mathrm{~g}$ were used in our study. They were kept in the vivarium at UNIMAR (University of Marília) under a dark/light cycle of 12 hours, room temperature of $22 \pm$ $2^{\circ} \mathrm{C}$, and relative air humidity of $60 \pm 5 \%$. After a period of seven days of acclimation to the laboratory, the animals were divided randomly into 4 groups $(n=12)$ treated for 40 days, as follows (animals of all groups received food ad libitum during the treatment period):

G1 received water and food ad libitum (Control Group);

G2 received condensed milk solution and food, both ad libitum;

G3 received $C$. longa by gavage route and water and food ad libitum;

G4 received condensed milk solution and food, both ad libitum, and $C$. longa by gavage route.

\section{Administration of C. longa}

The administration of the plant extracts was done twice a day (intragastric route): in the early morning and late afternoon and the treatment lasted for 40 days. The administered doses were $200 \mathrm{mg} / \mathrm{mL}$ of aqueous extract of the plant for G3 and G4 and saline solution for $\mathrm{G} 1$ and $\mathrm{G} 2$. Animals received $1 \mathrm{~mL}$ of the plant extract.

\section{Collection of Blood Samples and Determination of the Biochemical Profile, Atherogenic Index (AI) and Protection Index (PI)}

After treating animals for 40 days, they were anesthetized with Thiopental (sodium pentobarbital) until complete sedation, after which blood samples were drawn to determine their biochemical profile: total cholesterol, LDL-c, HDL-c, triglycerides, glycaemia and hepatic transaminases (ALT: aspartate transaminase and AST: alanine aminotransferase). The glucose and lipid levels were measured in $\mathrm{mg} / \mathrm{dL}$ and the enzymes in $U / L$ and the results were interpreted according to the ADA [15].

Atherogenic Index (Al) and Protection Index (PI) were calculated after Schulpis, Karikas [16] and also used by Munshi, Joshi, Rane [17]: Al = (Total cholesterol - HDL-c)/HDL-c.

\section{Statistical Analysis}

The results were expressed as mean \pm S.E.M. and evaluated by analysis of variance (ANOVA) complemented with Tukey test. The level of significance was set at $p<0.05$.

\section{RESULTS}

Figure 1 shows that there are no significant differences for body weight in the different groups.

Significant differences were observed between $G 1$ and G2, G1 and G3, G2 and G3 and G3 and G4 when comparing visceral fat. These results show that this type of diet increases visceral fat in the groups treated with condensed milk (Figure 2).

Glycaemia showed significant differences between G1 and G2 and between G2 and G3, showing that the hyper caloric diet increases plasmatic glucose levels and the treatment with the plant (G4) was not enough to prevent hyperglycemia (Figure 3). However, lower values of glucose in the blood were observed in the group that received hyper caloric diet and treatment with $C$. longa. 


\section{Weight increase}

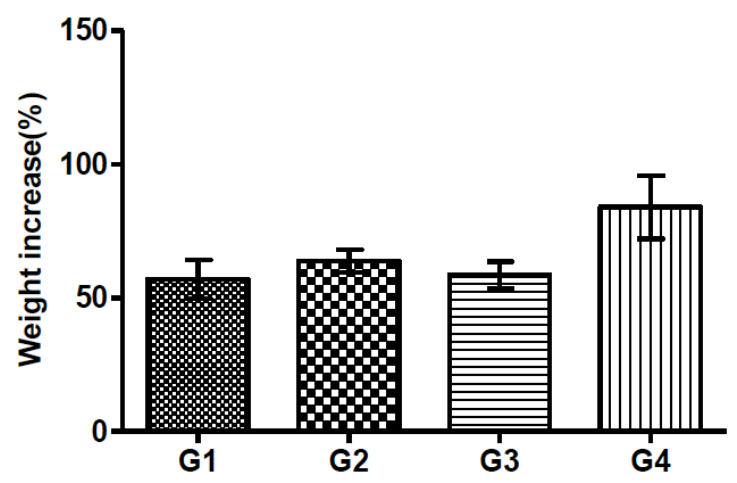

Figure 1: Values of weight (mean \pm S.E.M.) in G1 (control group), G2 (condensed milk), G3 (C. longa) and G4 (condensed milk and $C$. longa). No significant differences were found between the groups.

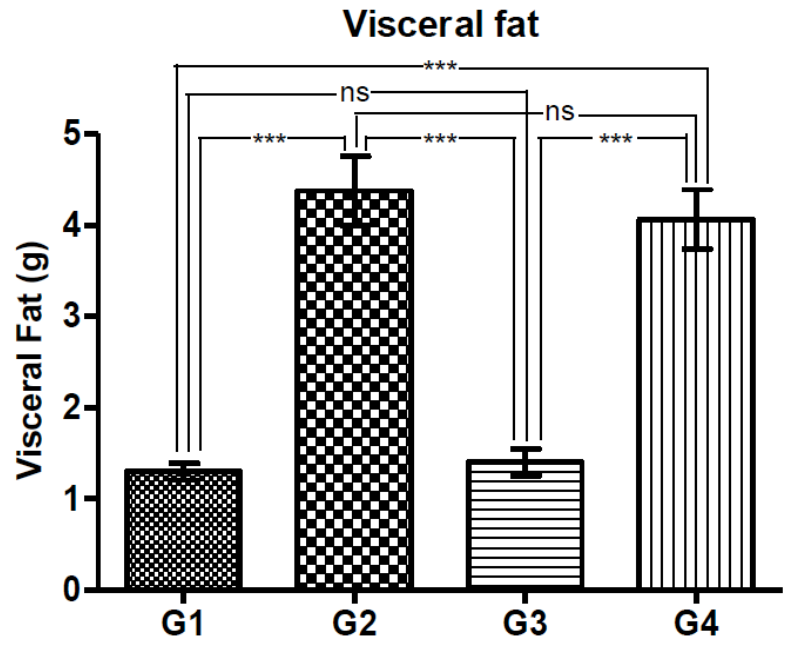

Figure 2: Values of visceral fat weight (mean \pm S.E.M.) in G1 (control group), G2 (condensed milk), G3 (C. longa) and G4 (condensed milk and $C$. longa). ns - not significant; ${ }^{* * *} p<0.0001$.

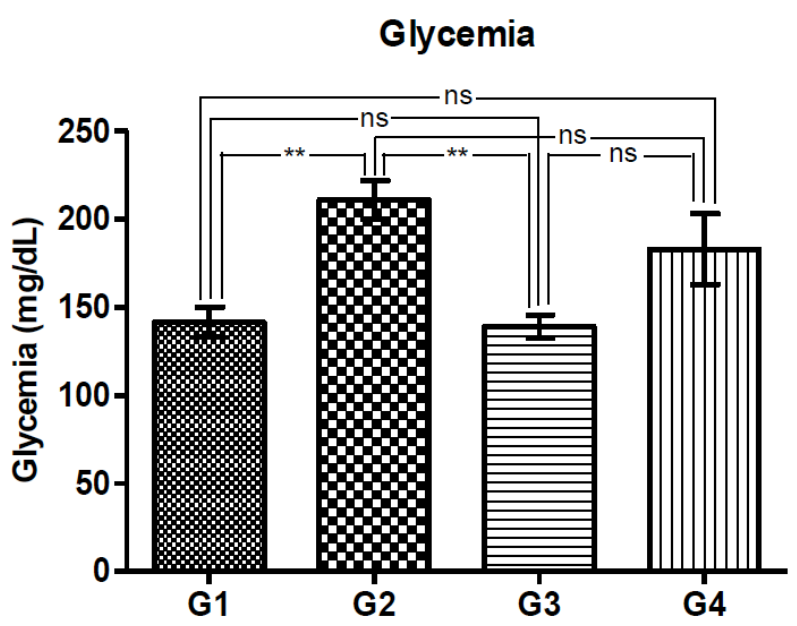

Figure 3: Values of glycaemia (mean \pm S.E.M.) in $\mathrm{G} 1$ (control group), G2 (condensed milk), G3 (C. longa) and G4 (condensed milk and $C$. longa). ns - not significant; ${ }^{* *} p<0.001$
Figure 4 shows that there are no significant differences in cholesterol levels in the different groups, even in those treated with hyper caloric diet.

\section{Cholesterol}

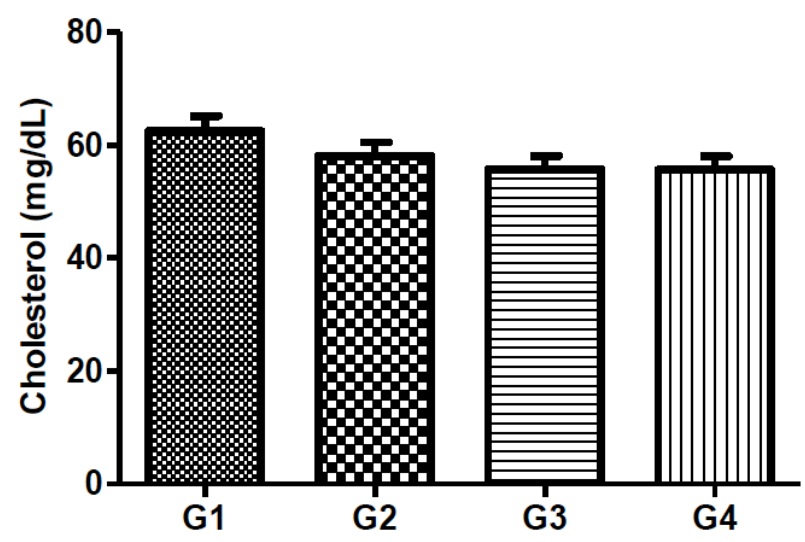

Figure 4: Values of cholesterol total (mean \pm S.E.M.) in $\mathrm{G} 1$ (control group), G2 (condensed milk), G3 (C. longa) and G4 (condensed milk and $C$. longa). No significant differences were found between the groups.

The levels of HDL-c were significantly different when comparing groups $\mathrm{G} 2$ and $\mathrm{G} 3$ showing that $C$. longa where not efficient to increase this lipoprotein (Figure 5).

\section{HDL-C}

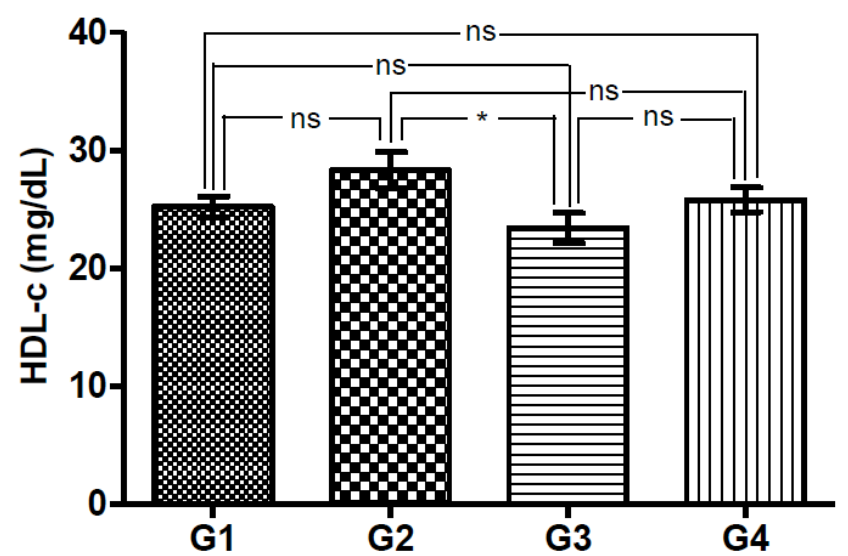

Figure 5: Values of HDL-c (mean \pm S.E.M.) in G1 (control group), G2 (condensed milk), G3 (C. longa) and G4 (condensed milk and $C$. longa). ns - not significant; ${ }^{*} p<0.05$.

Triglycerides showed significant differences between: G1 and G2; G1 and G4; G2 and G3; G3 and G4. The hyper caloric diet increases the levels of this lipid and the treatment with the plant is not enough to prevent alterations in animals fed with a hyper caloric diet (Figure 6) 4 when comparing to G3.

The hepatic enzymes AST were significantly different between $\mathrm{G} 1$ and $\mathrm{G} 2 ; \mathrm{G} 1$ and $\mathrm{G} 3, \mathrm{G} 1$ and $\mathrm{G} 4$, 
G2 and G4 and between G3 and G4 (Figure 7). Higher levels were observed in the control group.

\section{Triglycerids}



Figure 6: Values of triglycerides (mean \pm S.E.M.) in $G 1$ (control group), G2 (condensed milk), G3 (C. longa) and G4 (condensed milk and C. longa). ns - not significant; ${ }^{* *} p<0.001 ;{ }^{* \star *} p<0.0001$.

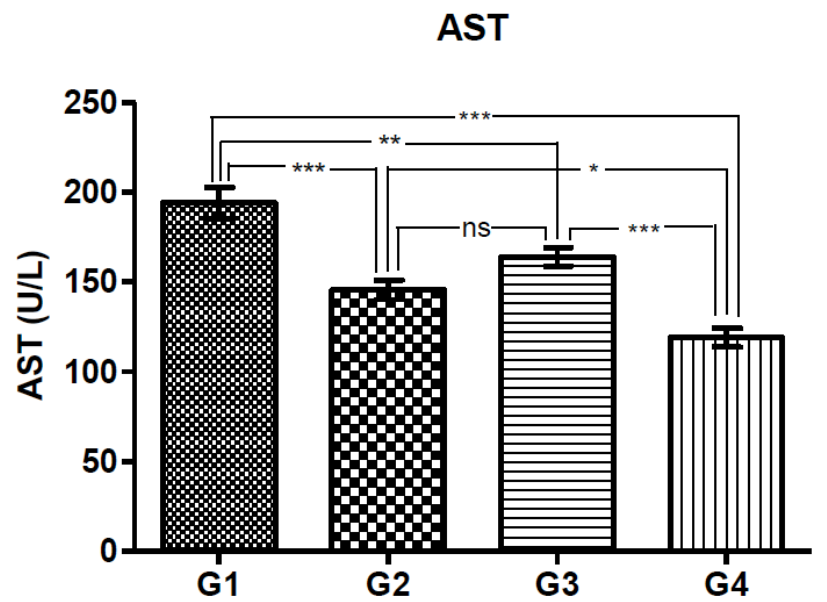

Figure 7: Values of AST (mean \pm S.E.M.) in G1 (control group), G2 (condensed milk), G3 (C. longa) and G4 (condensed milk and $C$. longa). ns - not significant; ${ }^{*} \mathrm{p}<0.05$; ${ }^{* *} p<0.001 ;{ }^{* * *} p<0.0001$.

AST were significantly different between $G 1$ and G2; G1 and G3; G1 and G4; G2 and G3; G3 and G4 (Figure 8). As in ALT levels, the higher values were found in the control group.

The Al were calculated among the groups and we observed that $C$. longa reduces the value in animals that received the hyper caloric diet and were treated with with the plant (Table 1).

When calculating the percentage of cardiovascular protection $(\mathrm{PI})$, we found that $\mathrm{C}$. longa reduces the risk of cardiovascular disease by $13 \%$ when the animals consume the hyper caloric diet.

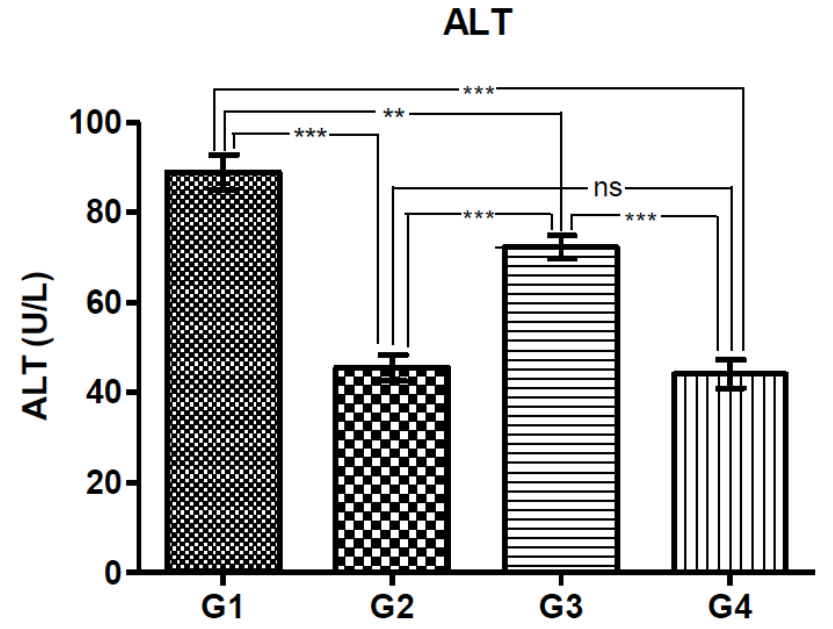

Figure 8: Values of ALT (mean \pm S.E.M.) in G1 (control group), G2 (condensed milk), G3 (C. longa) and G4 (condensed milk and $C$. longa). ns - not significant; ${ }^{\star *} p<0.001 ;{ }^{* *} p<0.0001$.

Table 1: Atherogenic Index (AI) in Groups G1 (Control Group), G2 (Condensed Milk), G3 (C. longa) and G4 (Condensed Milk and C. longa).

\begin{tabular}{|c|c|c|c|c|}
\hline & G1 & G2 & G3 & G4 \\
\hline \hline $\mathrm{Al}$ & 1,47 & 1,87 & 1,43 & 1,55 \\
\hline
\end{tabular}

\section{DISCUSSION}

C. longa is widely used in traditional medicine and several authors have shown importance in the treatment and prevention of many diseases as antioxidant, anti-inflammatory, anti-carcinogenic, antithrombotic, and cardiovascular protective effects. It possesses curcumin (diferuloylmethane) which is a yellow-colored bioactive constituent (polyphenol) responsible for the yellow color of the curry spice turmeric [18-20].

Our results show that visceral fat is increased in both groups of animals treated with hyper caloric diet and the use of $C$. longa improves this parameter but not significantly. The accumulation of lipids in adipocyte leads to obesity that is directly related to the metabolic syndrome, diabetes and cardiovascular diseases. Um et al. [21] showed that curcumim reduces the bodyweight and adipose tissue weight of mice treated with a high fed diet as well reduces the levels of total cholesterol, fasting glucose and insulin. It also has the ability to activate AMP-activated protein kinase (AMPK) and increase the gene expression of PPARa (peroxisome proliferator-activated receptor $\alpha$ ) and decreased the activity of Acetyl-CoA carboxylase 1 and fatty acid synthase. They also found that it protects 
against the development of hepatic steatosis by reducing hepatic fat accumulation. Other study show that gambigyeongsinhwan, a curcuminoid compound, inhibits lipid accumulation and mRNA levels of adipocyte-specific genes as peroxisome proliferatoractivated receptor $\mathrm{Y}$ (PPAR $\mathrm{Y}$ ) and activating adipose PPAR $\alpha$. These conditions lead to the decrease of body weight gain, adipose tissue mass, and visceral adipocyte size in rats [22].

Our results do not exhibit positive effects of the plant in the levels of total cholesterol and in the glycaemia, however decreased levels of glucose are found in the group treated with hyper caloric diet and $C$. longa. Similar results are found to the triglycerides levels. Tranchida et al. [23] also studied the use of this plant in rats fed with a high level of fructose and saturated fatty acid diet and found that $C$. longa did not prevent the observed increase in glycaemia, triglycerides, cholesterol and insulin levels. Lee et al. [23] did not found differences in glycaemia between users of turmeric. Contradicting these results, authors have shown that the anti-oxidant properties of curcumin may attenuate cardiotoxicity and may show protection against diabetic cardiovascular complications. Moreover, anti-diabetic effects of this component may occur due to its ability to reduce oxidative stress and inflammation. Associated to that, it may reduce blood glucose, and the levels of glycosylated hemoglobin in diabetic rats as well as advanced glycation, which takes to the reducing of production of advanced glycation end products that are related to the complications of diabetes. It also initiates a downregulation of nuclear factor-kappa $B$ and show benefits on the diabetes-induced endothelial dysfunction [18, 25-27]. There are evidences that curcumim may be related to the reduction of cholesterol levels protecting from the pathological changes observed in the atherosclerosis. Li et al. [26] evaluated the effects of curcumim in animals treated with high-fat diet and obtained significant reduction in cholesterol, LDL-c, triglycerides and increase in HDL-c levels [19, 27]. Lin et al. [20] showed a possible mechanism for understanding the anti-atherogenic effects of curcumin on attenuating the progression of atherosclerosis. They found that curcumin increases the expression of ATPbinding cassette transporter 1 , promoting cholesterol efflux from macrophage-derived foam cells, reducing cellular cholesterol levels and attenuating the progression of atherosclerosis $[20,28]$

Curcuminoids also were found to improve lipid profile in patients with metabolic syndrome after eight weeks of treatment [29]. Shin et al. [30] found that $C$. longa improves lipid profile, Atherogenic Index, reactive oxygen species and inflammatory cytokines (tumor necrosis factor- $\alpha$, and interlukin-6) in mice. Despite our results did not show improvement in the lipid profile, there was a reduction of $\mathrm{Al}$ in the animals treated with C. longa. Besides we also observed a PI of $13 \%$.

Our results show that the lowest values of the hepatic enzymes (AST and ALT) are in G4 and any other group showed values higher than control group. This leads to suppose that $C$. longa does not cause damages to the liver in the amount used in this experimental model. Nevertheless, Al-Rubaei, Mohammad, Ali [31] found significant increase in levels of ALT and AST in animals treated with curcumim. Kim et al. [32] studied the effects of fermented $C$. longa in rats under induced oxidative stress and verified it may protect liver against increase of AST and ALT under this condition.

Analyzing our results we may conclude that $C$. longa obtained from local markets may not be efficient to promote the benefits that several authors have shown in lipid and glycemic profile as well as in the body weight. One possibility to explain these data is that dietary curcumin is only poorly absorbed by the digestive tract what leads to its excretion [33]. This could confound the reasons of how dietary curcumin shows benefits in glycaemia, dyslipidemia and other diseases in some studies and no effects in others.

\section{AUTHORS' CONTRIBUTIONS}

ELG, ACA and SMB carried out the conception and design of the study, treated the animals and drafted the manuscript.

PCSB and DPC performed the statistical analysis.

MSSS prepared the extracts of the plants and treated the animals.

CGM, SSB and EPS performed the laboratorial analysis.

All authors read and approved the final manuscript.

\section{CONFLICT OF INTERESTS}

Authors declare no conflict of interests.

\section{REFERENCES}

[1] Barbalho SM, Bueno PC, Delazari DS, Guiguer EL, Coqueiro DP, Araújo AC, de Souza Mda S, Farinazzi-Machado FM, 
Mendes CG, Groppo M. Antidiabetic and antilipidemic effects of Manilkara zapota. J Med Food 2015; 18(3): 385-91. http://dx.doi.org/10.1089/jmf.2013.0170

[2] Sicras Mainar A, Navarro Artieda R, Ibáñez Nolla J.Economic Impact of Heart Failure According to the Effects of Kidney Failure. Rev Esp Cardiol 2014. pii: S0300-8932(14)00257-7. doi: 10.1016/j.recesp.2014.02.023.

[3] Lewitt MS, Dent MS, Hall K. The Insulin-Like Growth Factor System in Obesity, Insulin Resistance and Type 2 Diabetes Mellitus. J Clin Med 2014; 3(4): 1561-74.

\section{http://dx.doi.org/10.3390/jcm3041561}

[4] Klafke JZ, Arnoldi da Silva M, Fortes Rossato M, Trevisan G, Banderó Walker Cl, Martins Leal CA, Olschowsky Borges D, Chitolina Schetinger MR, Noal Moresco R, Medeiros Frescura Duarte MM, Soares Dos Santos AR, Nazário Viecili PR, Ferreira J. Antiplatelet, Antithrombotic, and Fibrinolytic Activities of Campomanesia xanthocarpa. Evid Based Complement Alternat Med 2012; 2012: 954748.

[5] Jungbauer A, Medjakovic S. Anti-inflammatory properties of culinary herbs and spices that ameliorate the effects of metabolic syndrome. Maturitas 2012; 71: 227-239.

http://dx.doi.org/10.1016/j.maturitas.2011.12.009

[6] Opara El, Chohan M. Culinary herbs and spices: their bioactive properties, the contribution of polyphenols and the challenges in deducing their true health benefits. Int $\mathrm{J}$ Mol Sci 2014; 15(10): 19183-202.

http://dx.doi.org/10.3390/ijms151019183

[7] Kumar S, Singh NN, Singh A, Singh N, Sinha RK. Use of Curcuma longa $L$. extract to stain various tissue samples for histological studies. Ayu 2014; 35(4): 447-51. http://dx.doi.org/10.4103/0974-8520.159027

[8] Kumar A, Chetia H, Sharma S, Kabiraj D, Talukdar NC, Bora U. Curcumin Resource Database. Database (Oxford) 2015; 2015: bav070. doi: 10.1093/database/bav070. Print 2015.

[9] Menon VP, Sudheer AAR. Antioxidant and anti-inflammatory properties of curcumin. Adv Exp Med Biol 2007; 595: 105125.

http://dx.doi.org/10.1007/978-0-387-46401-5 3

[10] Shishodia S, Chaturvedi MM, Aggarwal BB. Role of curcumin in cancer therapy. Curr Probl Cancer 2007; 31: 243-305. http://dx.doi.org/10.1016/j.currproblcancer.2007.04.001

[11] Hatcher H, Planalp R, Cho J. Curcumin: from ancient medicine to current clinical trials. Cell Mol Life Sci 2008; 65: 1631-1652.

http://dx.doi.org/10.1007/s00018-008-7452-4

[12] Bordoloi D, Roy NK, Monisha J, Ganesan P, Kunnumakkara AB. Multi-Targeted Agents in Cancer Cell Chemosensitization: What We Learnt from Curcumin Thus Far. Recent Pat Anticancer Drug Discov 2015.

[13] Pawar RS, Toppo FA, Mandloi AS, Shaikh S. Exploring the role of curcumin containing ethanolic extract obtained from Curcuma longa (rhizomes) against retardation of wound healing process by aspirin. Indian J Pharmacol 2015; 47(2): 160-6. http://dx.doi.org/10.4103/0253-7613.153422

[14] Gong C, Wu Q, Wang Y, Zhang D, Luo F, Zhao X. A biodegradable hydrogel system containing curcumin encapsulated in micelles for cutaneous wound healing. Biomaterials 2013; 34: 6377-87.

http://dx.doi.org/10.1016/j.biomaterials.2013.05.005

[15] American Diabetes Association. Standards of medical care in diabetes--2014. Diabetes Care 2014; 37(Suppl 1): S14-80. doi: $10.2337 /$ dc14-S014.

[16] Schulpis K, Karikas GA. Serum cholesterol and triglyceride distribution in 7767 school-aged Greek children. Pediatrics. 1998; 101(5): 861-4. http://dx.doi.org/10.1542/peds.101.5.861

[17] Munshi RP, Joshi SG, Rane BN. Development of an experimental diet model in rats to study hyperlipidemia andinsulin resistance, markers for coronary heart disease. Indian J Pharmacol 2014; 46(3): 270-6.

http://dx.doi.org/10.4103/0253-7613.132156

[18] Wongcharoen W, Phrommintikul A.The protective role of curcumin in cardiovascular diseases. Int J Cardiol 2009; 133(2): 145-51.

http://dx.doi.org/10.1016/j.ijcard.2009.01.073

[19] Han JM, Lee JS, Kim HG, Seol IC, Im HJ, Cho JH, Son CG. Synergistic effects of artemisia iwayomogi and curcuma longa radix on High-fat diet-induced hyperlipidemia in a mouse model. J Ethnopharmacol 2015. pii: S03788741(15)30033-7. doi: 10.1016/j.jep.2015.07.021

[20] Lin XL, Liu MH, Hu HJ, Feng HR, Fan XJ, Zou WW, Pan YQ, Hu XM, Wang Z. Curcumin Enhanced Cholesterol Efflux by Upregulating ABCA1 Expression Through AMPK-SIRT1LXRa Signaling in THP-1 Macrophage-Derived Foam Cells. DNA Cell Biol 2015. http://dx.doi.org/10.1089/dna.2015.2866

[21] Um MY, Hwang KH, Ahn J, Ha TY. Curcumin attenuates dietinduced hepatic steatosis by activating AMP-activated protein kinase. Basic Clin Pharmacol Toxicol 2013; 113(3): 152-7. http://dx.doi.org/10.1111/bcpt.12076

[22] Sung Roh J, Lee H, Woo S, Yoon M, Kim J, Dong Park S, Shik Shin S, Yoon M. Herbal composition Gambigyeongsinhwan (4) from Curcuma longa, Alnus japonica, and Massa Medicata Fermentata inhibits lipid accumulation in 3T3-L1 cells and regulates obesity in Otsuka Long-Evans Tokushima Fatty rats. J Ethnopharmacol 2015; 171: 287-94.

http://dx.doi.org/10.1016/j.jep.2015.05.056

[23] Tranchida F, Shintu L, Rakotoniaina Z, Tchiakpe L, Deyris V, Hiol A, Caldarelli S. Metabolomic and Lipidomic Analysis of Serum Samples following Curcuma longaExtract Supplementation in High-Fructose and Saturated Fat Fed Rats. PLoS One 2015; 10(8): e0135948. http://dx.doi.org/10.1371/journal.pone.0135948

[24] Lee MS, Wahlqvist ML, Chou YC, Fang WH, Lee JT, Kuan JC, Liu HY, Lu TM, Xiu L, Hsu CC, Andrews ZB, Pan WH. Turmeric improves post-prandial working memory in prediabetes independent of insulin. Asia Pac J Clin Nutr 2014; 23(4): 581-91. doi: 10.6133/apjcn.2014.23.4.24.

[25] Nabavi SF, Thiagarajan R, Rastrelli L, Daglia M, SobarzoSanchez E, Alinezhad H, Nabavi SM. Curcumin: a natural product for diabetes and its complications. Curr Top Med Chem 2015. http://dx.doi.org/10.2174/1568026615666150619142519

[26] Li ZY, Ding LL, Li JM, Xu BL, Yang L, Bi KS, Wang ZT. HNMR and MS based metabolomics study of the intervention effect of curcumin on hyperlipidemia mice induced by high-fat diet. PLoS One 2015; 10(3): e0120950.

http://dx.doi.org/10.1371/journal.pone.0120950

[27] Singh V, Jain M, Misra A, Khanna V, Prakash P, Malasoni R, Dwivedi AK, Dikshit M, Barthwal MK. Curcuma oil ameliorates insulin resistance \&amp; associated thrombotic complications in hamster \&amp; rat. Indian J Med Res 2015; 141(6): 823-32. http://dx.doi.org/10.4103/0971-5916.160719

[28] Maradana MR, Thomas R, O'Sullivan BJ. Targeted delivery of curcumin for treating type 2 diabetes. Mol Nutr Food Res 2013; 57(9): 1550-6.

\section{http://dx.doi.org/10.1002/mnfr.201200791}

[29] Panahi Y, Khalili N, Hosseini MS, Abbasinazari M, Sahebkar A. Lipid-modifying effects of adjunctive therapy with curcuminoids-piperine combination in patients with metabolic syndrome: results of a randomized controlled trial. Complement Ther Med 2014; 22(5): 851-7. http://dx.doi.org/10.1016/j.ctim.2014.07.006

[30] Shin HS, Han JM, Kim HG, Choi MK, Son CG, Yoo HR, Jo HK, Seol IC. Anti-atherosclerosis and hyperlipidemia effects of herbal mixture, Artemisia iwayomogi Kitamura and 
Curcuma longa Linne, in apolipoprotein E-deficient mice. J Ethnopharmacol 2014; 153(1): 142-50. http://dx.doi.org/10.1016/j.jep.2014.01.039

[31] Al-Rubaei ZM, Mohammad TU, Ali LK. Effects of local curcumin on oxidative stress and total antioxidant capacity in vivo study. Pak J Biol Sci 2014; 17(12): 1237-41. http://dx.doi.org/10.3923/pjbs.2014.1237.1241

[32] Kim Y, You Y, Yoon HG, Lee YH, Kim K, Lee J, Kim MS, Kim JC, Jun W. Hepatoprotective effects of fermented Curcuma longa L. on carbon tetrachloride-induced oxidative stress in rats. Food Chem 2014; 151: 148-53.

http://dx.doi.org/10.1016/j.foodchem.2013.11.058

[33] Dulbecco P, Savarino V. Therapeutic potential of curcumin in digestive diseases. World J Gastroenterol 2013; 19(48): 9256-70.

http://dx.doi.org/10.3748/wjg.v19.i48.9256

Received on 13-11-2015

Accepted on 24-12-2015

Published on 08-01-2016

DOI: http://dx.doi.org/10.6000/1927-5951.2015.05.04.3 